University of Michigan Law School

University of Michigan Law School Scholarship Repository

\title{
Child Labor Law Case, Commerce Power of Congress and Reserved Powers of the States
}

\author{
Henry M. Bates \\ University of Michigan Law School
}

Available at: https://repository.law.umich.edu/articles/893

Follow this and additional works at: https://repository.law.umich.edu/articles

Part of the Constitutional Law Commons, Courts Commons, Juvenile Law Commons, Legislation Commons, and the Supreme Court of the United States Commons

\section{Recommended Citation}

Bates, Henry M. "Child Labor Law Case, Commerce Power of Congress and Reserved Powers of the States." Mich. L. Rev. 17 (1918): 83-7.

This Response or Comment is brought to you for free and open access by the Faculty Scholarship at University of Michigan Law School Scholarship Repository. It has been accepted for inclusion in Articles by an authorized administrator of University of Michigan Law School Scholarship Repository. For more information, please contact mlaw.repository@umich.edu. 
Chitd Labor latw Case-Commerce Power of Congress and Reserved Powers of THE STATES.-The decision in the Child Labor Law case, Hammer v. Dagerhart, - U. S. -, 62 L. ed. -, decided June 3, I9I8, would have caused much less surprise twenty-five years ago than it did when announced last June, for it is based upon two constitutional provisions concerning which the much wider and more varied experience of the last quarter century had developed theories, better defined and sounder than those of the earlier period. Those two provisions are the Tenth Amendment regarding the powers reserved to the States and the Commerce Clause. There has been an astonishing amount of faulty reasoning about the Tenth Amendment in its relation 
to Federal powers. Over and over again courts and writers have argued as if certain powers, or powers of certain kinds had been reserved to the States and therefore that the Federal Government could not possibly have or exercise powers that touched those fields; or, to put it otherwise, that the Federal Government could not exercise even its granted powers, as those over commerce or to make treaties, if such exercise would affect matters concerning which the States also possessed power. But this is a diametrically wrong way to approach the distribution of powers between the Federal and the State Governments. Certain powers have been given to the Federal Government. In the nature of the case, and as the Supreme Court has declared repeatedly, these powers, many of them stated only in geenral outline, are and must be capable of indefinite expansion, or more accurately their application is and must be to a changing and always increasing number of objects and situations.

As this process of extending the application of the commerce power to new subjects proceeds, it will necessarily follow in a great many cases that powers of the States, the exercise of which would conflict with these exertions of Federal power, must be suspended pro tanto during the life of the Federal law. There are many familiar examples of this. The States may in general adopt and administer their own laws of quarantine, of pilotage, of the regulation of internal traffic, and the sale of goods, but if Congress should enact a law, as unquestionably it has the power to do, regulating quarantine at all ports, all State laws in conflict therewith would necessarily be suspended at least during the life of the Federal quarantine statute. Morgan S. S. Co. v. La. Bnard of Health, ir8 U. S. 455, 463. The same results would follow the enactment of a Federal pilotage scheme. Cooley v. Board of W'ardens of Philadelphio, 12 How. 299 ; Anderson v. Pac. S. S. Co., 225 U. S. 187.

Congressional regulations of interstate commerce as to subjects of transportation and as to methods of transportation have caused innumerable restrictions upon the power of the States in regard to these matters. Gibbons v. Ogden, 9 Wheat. I; Brown v. Maryland, 12 Wheat. 419; The Daniel Ball, 1o Wall. 557; Northern Pac. Ry. v. Washington, 222 U. S. 370; Wabash, etc. Ry. Co. v. Illinois, 118 U. S. 557; Mich. Cent. Ry. v. Vreeland, 227 U. S. 59; Second Employers' Liability Cases, 223 U. S. I.

To come still nearer to the case in hand, when Congress enacted the Pure Food Law, it of course prevented the transportation into other states of food made or put up in violation of its terms, thus diminishing the market and hence indirectly affecting manufacture of goods even though made in complete conformity with the State law. Seven Cases of Eckman's Alterative v. U. S., 239 U. S. 510. When Congress prohibited the carrying of lottery tickets in interstate commerce, even though the lottery as an institution were legally recognized by the State, it necessarily diminished the importance and value which the institution would have had except for this restriction.' Lottery Case, 188 U. S. 321.

The Webb-Kenyon Act, Act of March I, 1913, 37 Stat. 669, c. 90, by which Congress authorized the States to exercise their police power in regard to the importation and use of liquor from other states has been held to be an exercise of the Congressional power over commerce whereby the law of one 
State may effectively restrict the market for goods manufactured in another State, though the manufacture in such other State were entirely lawful. Clark Distilling Co. v. Western Md. Ry. Co., 242 U. S. 3II. Unless the proposed Federal prohibition amendment shall be adopted, undoubtedly each state may prohibit or permit by license or otherwise the sale and use of liquor. Nevertheless by the Congressional act a partial prohibition in interstate commerce is in effect produced, and that prohibition limits the powers of States quite as effectively as the Supreme Court says it was sought to be limited by the Child Labor Law.

The same problem may be approached from the point of view of the exercise of aother power and with the same results. The President is given the power to make treaties by and with the advice and consent of the Senate. (Art. II, § I, Cl. 2.) Treaties may concern any subject proper for international treatment not prohibited by the Constitution. They may then and commonly do relate to many matters of great importance to the State internally, such as the purchase, sale, holding, and descent of real property, the right of the nationals of other powers to engage in business in the United States, and an indefinite number of matters more or less associated with these. The United States has repeatedly executed treaties affecting these matters, which are of course subject in general to the powers of the States, and yet when the paramount power of the national government is properly exercised the power of the State government is necessarily correspondingly restricted or suspended. Fairfax's Devisees, 7 Cranch 627; Ware v. Hylton, 3 Dall. 242; Hauensiein v. Lynham, 100 U. S. 483.

The restricting effect-which the exercise of the treaty making power has upon State authority over matters which would ordinarily be regarded as within the so-called powers of the States has been admirably discussed in Corwin's "The Treaty Making Power and National Supremacy." The contrary view, but one which seems indefensible is ably presented in Tucker's "I imitations Upon the Treaty Making Power."

It is submitted that the theoretically correct mode of determining what powers are reserved to the State or the people under the Tenth Amendment is to first ascertain what powers are expressly or impliedly granted to the Federal Government or prohibited to the States by the Federal Constitution and to subtract these from the totality of governmental powers. And this is the mode actually taken by the Supreme Court in the great majority of cases, some of which have been cited above.

If this reasoning be sound, it follows that there were not two but only one real question to be asked and answered by the Supreme Court in deciding the Child Labor case, and that question was: Is the Child Labor Law within the scope of the authority conferred upon Congress by the Commerce Clause? With entire deference we believe that the answer to this question should have been in the affirmative and that is the view taken by the four dissenting Justices of the Supreme Court and convincingly presented in the opinion by Mr. Justice HoLMES. In other words, if this is a proper regulation of interstate commerce, the law does not infringe at all upon the socalled reserved powers of the States. In taking up this question the Supreme 
Court seems to us to have fallen into a logical fallacy at the very outset of the majority opinion, and then to have put an interpretation upon several of its former decisions which is not tenable. Mr. Justice DAY, who has delivered many opinions showing an enlightened and forward looking view concerning legislation dealing with social problems, quotes from Gibbons v. Ogden, as follows:

"It is the power to regulate, that is to prescribe the rule by which commerce is to be governed."

about which he remarks:

"In other words, the power is one to control the means by which commerce is carried on, which is directly the contrary of the assumed right to forbid commerce from moving and thus destroying it as to particular commodities. But it is insisted that adjudged cases in this court establish the doctrine that the power to regulate given to Congress incidentally includes the authority to prohibit the movement of ordinary commodities and therefore that the subject is not open for discussion. The cases demonstrate the contrary. They rest upon the character of the particular. subjects dealt with and the fact that the scope of governmental authority, state or national, possessed over them is such that the authority to prohibit is as to them but the exertion of the power to regulate."

But is it not quite clear that the power "to prescribe the rule by which commerce is to be governed", which is Chief Justice Marshali's formula, is very much more comprehensive than "the power to control the means by which commerce is carried on", which is Mr. Justice Day's statement? To prescribe rules by which commerce is to be governed is obviously to control the whole life of commerce including dealing not only with the instrumentalities of commerce but with commerce itself and its subject matter. Perhaps it is the narrower interpretation that the power includes only the right to control the means of commerce which. led the majority of the court in the present case to the conclusion that Congress has no power to prohibit commerce except where the subject matter of such commerce is in and of itself pernicious and productive of injury after the act of commerce is closed. With great respect it is submitted that this cannot be the correct view. That a power to regulate includes the power to prohibit in proper cases has been established in many kinds of regulation. It is sufficient here to refer to prohibitions of commerce of which well known examples may be found in the following cases. In re Rahrer, 140 U. S. 545 (liquor); the Lottery case, I88 321; Hipolite Egg Co. v. U. S., 220 U. S. 45 (food); U. S. v. Lexingten Mill \& Elevator Co., 232 U. S. 399; Hoke v. U. S., 227 U. S. 308 (white slave); Caminetti v. U.S., 242 U. S. 470 (white slave).

The court, in seeking to distinguish these cases from the one before it in order to establish its proposition that prohibition is permissible under the commerce clause only when the subject matter of such commerce may be productive of injury arising after the commerce is completed, falls into what 
seems to us an error which perhaps may be traced to a sentence in $U . S$. v. E. C. Kright Co., 156 U. S. I, to the effect that manufacture precedes commerce. This is of course true. But it is an obvious non-sequitur to say that therefore Congress cannot exert its power over commerce merely because such exercise would through commerce indirectly affect manufacture. Certainly the commerce power was not given to Congress for the sole purpose of regulating and promoting commerce as an end in and of itself. There is abundant evidence that it was given not only to prevent the abuses of which some of the states had been guilty in dealing with commerce under the Articles of Confederation and of promoting commerce as a means of promotion of the general welfare, but also for the purpose of securing that general welfare by any regulation of commerce productive of such effect and not forbidden by other clauses in the constitution. What possible difference can it make whether the evil aimed at may have been caused before the particular act of transportation has taken place or after it? If the privilege of such interstate transportation and commerce be greatly enlarged the market for the goods transported thus increases the scale of manufacture and the evil which such manufacture produces. That evil in this case includes of course the injury to the child's health, moral and spiritual welfare, and the cutting off of its opportunity for a reasonable amount of education.

The dissenting opinion makes it clear that the real and substantial infraction of the powers of the state governments is caused by denying to Congress the powcr to regulate this matter and thus putting it within the power of the several states to ship their goods into other states, not only without the consent of the latter but contrary to their established public policy in regard to child lahor or whatever else may be involved. Of course the states did not have such extraterritorial power before the adoption of the constitution, and it is absurd to suppose that it was intended to be given to them by that instrument. In the argument of the present case, the government showed very clearly that one effect of the existence of legislation forbidding child labor in some states and the non-existence of such legislation in others is to drive the greedy and conscienceless manufacturers from the states with this enlightened legislation to those which have it not. Not only that, but the goods made in the latter class of states must now be received and may be sold in the other states and to consumers who may have conscientious scruples against the use of such goods and who have no means of knowing whether in fact child labor has been employed in the manufacture.

The scientific and popular opinion is so strong for the prohibition of child labor in this country that it is certain to be obtained sooner or later. It would seem clear that this object may be obtained by an exercise of the taxing power of Congress under the doctrine laid down in McCray v. U.S., I05 U. S. 27. H. M. B. 